\title{
26 Resarch Soure \\ Effects Of Spent Engine Oil On Soil Characteristics And Selected Phytochemicals In Amaranthus Hybridus
}

\section{Arathy Arunan Swapna}

All Saints' College

Rajani Vijayammal ( $\square$ rajanijayasankar@gmail.com )

All Saints' College, TVPM, Kerala

Dhanya Surendran Radha

KSMDB College: Kumbalathu Sankupillai Memorial Devaswom Board College

\section{Research Article}

Keywords: Spent engine oil, Amaranthushybridus, Phytochemicals, Soil pollution, Soil nutrients, Anti nutritional factors

Posted Date: October 25th, 2021

DOI: https://doi.org/10.21203/rs.3.rs-939651/v1

License: (1) (1) This work is licensed under a Creative Commons Attribution 4.0 International License. Read Full License 


\section{Abstract}

Spent engine oil is hazardous to the environment. Indiscriminate disposal of spent engine oil drain from engines after servicing has been found to affect the environment. An experiment was carried out to determine the effect of spent engine oil pollution on soil characteristics and the ability of Amaranthushybridusto thrive in the soil supplemented with varying concentrations of spent engine oil ranging from $50-300 \mathrm{~mL}$. Soil pH was slightly increased due to spent engine oil pollution. Nitrogen, phosphorus and potassium were reduced in the polluted soils and the soil organic carbon was increased. Soil samples polluted with spent engine oil showed increased bulk and particle densities and also decreased water holding capacity and porosity. The spent engine oil pollution affected the phytochemicals and resulted in the increased concentration of anti- nutrient tannin and decreased concentrations of nutrients like alkaloids, flavonoids, etc. The results of this study suggest that spent engine oil at any concentration seriously affects the soil properties and phytochemical analysis showed the inhibitory effects of spent engine oil on Amaranthushybridus.

\section{Introduction}

Oil pollution is a serious threat to the environment and the ecosystem as a whole. Oil spill include any spill of crude oil or oil distilled products such as gasoline, diesel fuels, jet fuels, kerosene, Stoddard solvents, hydraulic oils, lubricating oils, etc., that can pollute the land, air and water environments. The soil system was considered to be the most important long term repository for these toxic compounds mainly PAHs and it also considered to be a steady indicator of the state of environmental pollution. Oil pollution changes the $\mathrm{pH}$ of the soil and thereby affects the physical, chemical and biological properties of the soil. Pore spaces in the soil might be clogged which could reduce soil aeration and water infiltration. It increases the bulk density subsequently affecting plant growth. Oil pollution also reduces and restricts the soil permeability. Oil pollution in soil may leads to the development of essential and nonessential elements in soil and the eventual translocation in plant tissues. This study was carried out with the sole objective to provide information on the effect of oil pollution on soil properties and the growth response of Amaranthushybriduscrops to spent engine oil with the view to establish minimum concentration of this contaminant could pose hazardous effects on its growth.

\section{Materials And Methods}

\section{Materials}

The soil samples were collected from a domestic area at Anayara, Thiruvananthapuram district, Kerala. Soil samples were collected in 6 polythene bags. Better growing seeds of Amaranthushybridus(plate 1) used for the study were purchased from Agro bazar. Spent engine oil was obtained from an auto-mechanic workshop at Thiruvananthapuram.

\section{Plate 1: Amaranthushybridus}

\section{Methods}

\section{Treatment of soil samples}

Seedlings used for the study were raised from Amaranthus seeds and were planted in a grow bag. Seedlings were allowed to grow on the grow bags for 14 days to enable them attain a height range of 8-12 cm. 5 grow bags filled with soil samples were indicated as A, B, C, D and E for easy identification. The set A was polluted by soaking with $50 \mathrm{ml}$ of 
spent engine oil, sample B by $100 \mathrm{ml}$, sample C by $200 \mathrm{ml}$ and finally sample D by $300 \mathrm{ml}$ of spent engine oil.

Treatment of the soil samples were carried out by manual mixing of soil with known volume of oil. The mixing was gradually done to obtain a thorough and even mixing. Soaked soil samples were left for 24 hours after which seedlings are planted in the bags. The set $E$ served as the control which is devoid of spent engine oil. Seedlings of equal height $(11 \mathrm{~cm})$ were selected and transplanted into the grow bags in the order of $A, B, C, D$ and $E$. Two seedlings were planted in a bag representing each treatment. Water was added to all samples daily. The rate of growth, seedling height and number of leaves were observed at intervals.

\section{Analysis of soil parameters}

a. Estimation of Soil pH (S D Sawarkar 2012)

b. Estimation of Electrical Conductivity (S D Sawarkar 2012)

C. Estimation of Soil Organic Carbon (S D Sawarkar 2012)

d. Estimation of Nitrogen (Bremner 1965)

e. Estimation of Phosphorus (Bray and Kurtz 1945)

f. Estimation of Potassium (Ghoshet al., 1983)

g. Estimation of Water Holding Capacity (Viji and Prasanna P. Rajesh 2012)

h. Estimation of Bulk Density, Particle Density and Porosity (Viji and Prasanna P. Rajesh 2012)

\section{Analysis of Phytochemicals}

a. Estimation of Flavonoids (Zshishenet al., 1999)

b. Estimation of Total Phenols (Chun et al., 2003)

C. Estimation of Alkaloids (JoyammaVarkey andSeema S Nair, 2019)

d. Estimation of Tannin (Selvakumaret al., 2019)

e. Estimation of Phytic acid (Camire and Clydesdale, 2006)

f. Estimation of Saponin(Makkar et al., 2007)

\section{Results And Discussion}

\subsection{Effects of Spent Engine Oil on Soil Characteristics 3.1.1. Soil pH}

In the analysis of physico-chemical parameters of soil, the $\mathrm{pH}$ was found to be higher in soil sample $\mathrm{D}$ and it was lower in control soil sample $\mathrm{E}$ (Table 1). The soil became slightly alkaline in the sample $\mathrm{D}$. The $\mathrm{pH}$ of the soil samples treated with 50, 100, 200 and $300 \mathrm{ml}$ spent engine oil was 6.3, 6.5, 6.9 and 7.3 respectively (Table 1). This was agreed with the findings of Odjegba $\mathrm{V} J$ and Atebe $\mathrm{J} O$ (2007). They found that, soil pH was increased, when amended with used engine oil. The control (unpolluted) soil had a $\mathrm{pH}$ value of 7.1 and oil polluted soil had $\mathrm{pH}$ values ranging from 7.1 - 7.5 .

Also Nwite J N and Alu M O (2015) found that, pH was generally higher than the control and increased with increase in spent engine oil application across treatments. These findings may contradictory with the results of Oyem and 
Isama Lawrence (2013). That is spent engine oil pollution decrease the soil pH. Some other researchers found no variations on the soil $\mathrm{pH}$ by the addition of spent engine oil. There was no significant difference $(P>0.05)$ in the soil $\mathrm{pH}$ between the control and the contaminated soil in the study by Okonokhua B $\mathrm{O}$ et al., (2007). The optimum soil pH for the growth of plants was between 6 and 7. At this $\mathrm{pH}$, the seeds need good fertile soil and adequate moisture to germinate. High or low pH cause deficiencies in essential nutrients that plants need to grow and causes stunted growth and yellowing of leaves.

\subsubsection{Soil Electrical conductivity}

Electrical Conductivity was higher in the control soil sample $\mathrm{E}(0.41 \mathrm{mhos} / \mathrm{cm})$ and it was lower in soil sample $\mathrm{D}(0.21$ mhos/cm) (Table 1). Electrical Conductivity of spent engine oil treated soil samples $A, B, C$, and $D$ were found to be $0.26,0.26,0.24$, and 0.21 respectively. The application of spent engine oil reduced the availability of exchangeable cations. This could be due to the presence of enhanced nutrients such as available Phosphorus. Kayodeet al., in 2009 and Uhegbuet al., in 2012 reported that spent engine oil pollution in the soils reduced the concentration of soil exchangeable cations.

\subsubsection{Soil Organic Carbon}

Organic carbon was higher in the soil sample D (2.07\%) and it was relatively lower in control soil sample $E(1.67 \%)$ (Table1). Amount of organic carbon in spent engine oil treated soil samples A, B, C and D were 1.71\%, 1.95\%, 1.98\%, and $2.07 \%$ respectively (Table 1). According to Ekundayoet al. (1989), organic carbon content in the soil can be altered by spent engine oil pollution. Similarly, Okonokhua B O, et al., (2007) found that, the organic C (3.68) of the contaminated soils increased compared to the control (2.07). The organic carbon content was highest at the point of discharge of the spent engine oil (2-2.9\%) having a mean value of $2.5 \%$, the surrounding soil and control had the same mean OC value of $1.2 \%$ was observed in the study conducted by Otobong B. Iren and Victoria F. Ediene (2017). Nitrogen and organic carbon increased markedly with an increase in the oil treatment concentration for all the crops were found in a study conducted by Uquetan U I et al., in 2017. Similar results are also obtained in the study of Nwite $\mathrm{J} N$ and Alu M O (2015). The percentage of organic carbon (\%OC) across the treatments of spent engine oil was significantly $(P<0.05)$ higher than control.

\subsubsection{Soil Nitrogen}

Nitrogen was found to be higher in the control soil sample $\mathrm{E}$ (Table 1). As the treatment concentration increased, the nitrogen content in the soil samples was decreased. The amount of nitrogen in the soil samples A, B, C, and D were $191,184,176$ and $165 \mathrm{~kg} / \mathrm{ha}$ respectively. The nitrogen content in the control soil sample was $203 \mathrm{~kg} / \mathrm{ha}$ (Table 1). Similar results are found in the results of Kayodeet al. (2009). They observed that, there was reduced nitrogen in soil treated with spent lubricant oil. Many authors prove that pollution by petroleum products may cause a reduction in nitrogen levels in plants (Wyszkowski and Wyszkowska2005). Soils contaminated with petroleum substances causes changed nitrogen-carbon ratio mainly due to the presence of hydrocarbons. This contributes to the inhibition of many nitrogen involving reactions in the soil (regarding both mineral and organic forms of nitrogen), as well as to a reduction in the intensity of ammonification and nitrification (Adam and Duncan 2003; Kucharski and Jastrzębska2005) which may explain the reduced levels of nitrogen in the soil.

\subsubsection{Soil Phosphorus}

Phosphorus content was highest in the control soil sample $E$ (Table 1). Phosphorus content in the spent engine oil treated soil samples A, B, C and D were 86, 74, 70 and $64 \mathrm{~kg} / \mathrm{ha}$ respectively. Phosphorus was reduced in the oil contaminated soils compared to the control and this agrees with the findings of Ogboghodoet al., (2004) and Okonokhua B O et al., (2007). In the study of Okonokhua B O et al., (2007), the phosphorus in the control was 5.76 
ppm and it progressively decreased into $4.85 \mathrm{ppm}$ in the treated soil samples. In a study of Uquetan U I et al., (2017) observed that the available phosphorus content decreased from $93.40 \mathrm{mg} / \mathrm{kg}$ in the control to $50.24 \mathrm{mg} / \mathrm{kg}$ in treatment concentration of $800 \mathrm{ml} / 20 \mathrm{~kg}$ and further decreased to $41.0 \mathrm{mg} / \mathrm{kg}$ as the treatment concentration increased. Similarly, Nwite J N and Alu M O (2015) found that, available phosphorus of control was significantly $(P<0.05)$ higher than those of spent engine oil application across the treatments. Available phosphorus decreased with increase in spent engine oil application with the one applied at $1.0 \mathrm{l} /$ poly bag giving the least value of $10.20 \mathrm{mg}$ $\mathrm{kg}-1$. The available phosphorus of control was $83 \%$ higher than the one applied at $1.0 \mathrm{l} / \mathrm{poly} \mathrm{bag}$.

\subsubsection{Soil Potassium}

Potassium was higher in the soil sample E (220 kg/ha) and it was lower in the soil sample D (103 kg/ha) (Table 1). Potassium content in spent engine oil treated soil samples A, B, C and D are 152, 143, 121 and $103 \mathrm{~kg} / \mathrm{ha}$ respectively. Similar observations are also found in the study of Nwite $\mathrm{J} \mathrm{N}$ and Alu M O in 2015. Exchangeable cations of potassium were generally higher in control than in different levels of spent engine oil application. The exchangeable cations of $\mathrm{K}$ and $\mathrm{Mg}$ were decreased with increasing spent engine oil pollution in the soil.

\subsubsection{Soil Water Holding Capacity}

Water holding capacity of the soil was higher in the soil sample $\mathrm{E}(43.84 \%)$ and it is lower in the soil sample D (31.46\%) (Table1). The water holding capacity of soil samples A, B, C and D are $41.10 \%, 38.70 \%, 31.53 \%$, and $31.46 \%$ respectively. This observation was agreed with the study of Rasaiahet al., (1990). They observed a decreased soil water holding capacity in soils polluted with spent hydrocarbon oil. Spent lubricant oil pollution in the soil causes an increased bulk density, decreased water holding capacity and aeration propensity (Kayodeet al., 2009). Agbogidi and Enujeke (2012) reported that plots with spent oil contamination had reduced water infiltration and percolation. Reduced hydraulic conductivity results in a low "soil water transmission". It also leads to less water availability for plant roots to access for photosynthetic processes.

\subsubsection{Soil Bulk Density}

Bulk density was higher in the soil sample D (1.40g/cc) (Table 1$)$ compared to the control soil sample. Bulk density of the soil samples A, B, C and D, treated with spent engine oil are $0.98,1.17,1.24$, and $1.40 \mathrm{~g} / \mathrm{cc}$ respectively. The bulk density of control soil sample was $1.00 \mathrm{~g} / \mathrm{cc}$. This result was agreed with the study done by Ewetola E Abosede (2013) observed that crude oil pollution increased bulk density and reduced total porosity of the soil. When comparing the control soil with polluted soil, the bulk density was increased by $7.1 \%$ and also the total porosity was reduced by $8.5 \%$. This may result as blockage of pores spaces with the pollutant. Similar observations are also found in the study of Oyem and Isama Lawrence (2013). In this, values of the average bulk density obtained from Orgonoko and Arunton areas were $1.31 \mathrm{~g} / \mathrm{cm} 3$ and $1.27 \mathrm{~g} / \mathrm{cm} 3$ respectively. But the oil impacted sample has the value of $4.16 \mathrm{~g} / \mathrm{cm} 3$.

Similarly Kayodeet al., in 2009, observed an increased bulk density in soils polluted with spent lubricant oil. Effect of bulk density of the soil by spent engine oil pollution is evident in the study of Nwite J N and Alu M O (2015) that, bulk density of spent engine oil treated soil was significantly $(P<0.05)$ higher than the control. The significant increase in bulk density of spent engine oil treated soil could be attributed to compaction resulting from oil contamination as well as reduced porosity.

\subsubsection{Soil Particle Density}

Particle density was higher in the soil sample D (Table 1). The particle density of the soil samples A, B, C and D are $1.79,1.96,2.01$ and $2.03 \mathrm{~g} / \mathrm{cc}$ respectively. Particle density of the control was $1.62 \mathrm{~g} / \mathrm{cc}$, which was less than the particle densities of soil samples A, B, C and D. Increased bulk density of spent engine oil treated soil also affect the 
particle density of the soil. Compaction of soil results in increased particle density and also caused reduction in total porosity as the pore spaces could have been clogged by dispersed soil particles (Nwite J N and Alu M 0, 2015).

\subsubsection{Soil Porosity}

The porosity of soil sample was higher in the control soil sample E (44.13\%). The porosity of spent engine oil treated soil samples A, B, C and D are $39.63 \%, 37.07 \%, 32.36 \%$, and $17.09 \%$ respectively. Porosity was very less in the soil sample D (Table 1). This result was agreed with the study of Nwite $\mathrm{J} \mathrm{N}$ and Alu M O (2015). There was an inverse relationship between bulk density and total porosity of the soil. Spent engine oil pollution increased the total porosity of the soils. This was mainly because of the compaction of the soils. In the polluted soils the pore spaces have been clogged by dispersed soil particles.

Table 1

Analysis of soil parameters

\begin{tabular}{|c|c|c|c|c|c|c|c|c|c|c|}
\hline Soil Sample & $\mathrm{pH}$ & $\begin{array}{l}\mathrm{EC} \\
\mathrm{mhos} / \mathrm{cm}\end{array}$ & $\begin{array}{l}\text { Org. C } \\
\text { (\%) }\end{array}$ & $\begin{array}{l}\mathrm{N} \\
(\mathrm{kg} / \mathrm{h})\end{array}$ & $\begin{array}{l}P \\
(\mathrm{~kg} / \mathrm{ha})\end{array}$ & $\begin{array}{l}\mathrm{K} \\
\text { (kg/ha) }\end{array}$ & $\begin{array}{l}\text { WHC } \\
(\%)\end{array}$ & $\begin{array}{l}B D \\
(g / c c)\end{array}$ & $\begin{array}{l}P D \\
(g / c c)\end{array}$ & $\begin{array}{l}\text { Porosity } \\
\text { (\%) }\end{array}$ \\
\hline $\begin{array}{l}\text { A } \\
(50 \mathrm{~mL})\end{array}$ & 6.3 & 0.26 & 1.71 & 191 & 86 & 152 & 41.10 & 0.98 & 1.79 & 39.63 \\
\hline $\begin{array}{l}\text { B } \\
(100 \mathrm{~mL})\end{array}$ & 6.5 & 0.26 & 1.95 & 184 & 74 & 143 & 38.70 & 1.17 & 1.96 & 37.07 \\
\hline $\begin{array}{l}\text { C } \\
(200 \mathrm{~mL})\end{array}$ & 6.9 & 0.24 & 1.98 & 176 & 70 & 121 & 31.53 & 1.24 & 2.01 & 32.36 \\
\hline $\begin{array}{l}\text { D } \\
(300 \mathrm{~mL})\end{array}$ & 7.3 & 0.21 & 2.07 & 165 & 64 & 103 & 31.46 & 1.40 & 2.03 & 17.09 \\
\hline $\begin{array}{l}\text { E } \\
\text { (control) }\end{array}$ & 6.2 & 0.41 & 1.67 & 203 & 92 & 220 & 43.84 & 1.00 & 1.62 & 44.13 \\
\hline
\end{tabular}

\subsection{Effect on selected phytochemicals of Amaranthushybridus}

\subsubsection{Estimation of Alkaloids}

Alkaloid content in the leaf samples was high in the control E compared to the A, B, C, and D samples (Table 2). Alkaloids in the leaf samples $A, B, C$ and $D$ are $2.45,2.18,1.83$, and $0.98 \mathrm{mg} / 100 \mathrm{gm}$ respectively. This observation was agreed with the results of OnyegemOkerentaet al., (2002). In their study, the alkaloid content in the plant material was significantly decreased due to the spent engine oil pollution. In a study conducted by Emurotu and Marvelous Olubunmi (2019), the bean plant grown in crude oil contaminated soil only alkaloid was present while the rest of phytochemicals (phenol, flavonoids) were absent.

\subsubsection{Estimation of Flavonoids}

Flavonoid content in the control sample was $0.82 \mathrm{mg} / 100 \mathrm{gm}$ and it was higher than that of the samples $A, B, C$ and D. In a study conducted by Emurotu and Marvelous Olubunmi (2019), the bean plant grown in crude oil contaminated soil only alkaloid was present while the rest of phytochemicals were absent. Total phenol and flavonoid contents 
showed a decline of $57.6 \%$ and $41.3 \%$ respectively in the Amaranthuscruentus samples exposed to PAH pollution (Tandey R et al., 2020).

\subsubsection{Estimation of Saponin}

The content of saponin in the leaf sample was higher in the control E (Table 2). Saponin content in leaf samples of the plants grown in the soil samples $A, B, C$, and $D$ were $1.21,1.03,0.87$ and $0.73 \mathrm{mg} / 100 \mathrm{gm}$ respectively. This result was agreed with the findings of OnyegemOkerentaet al., (2002). The impact of the pollution results in a marked reduction in saponin concentration in $A$. esculentus as the level of pollution in the soil increased respectively. The responsive reduction in the saponin content could be attributed to the higher levels of phytotoxic damage to the plant that might have been caused by spent engine oil pollution.

\subsubsection{Estimation of Tannin}

The tannin concentration was higher in the plant grown in highly polluted soil sample D $(0.91 \mathrm{mg} / 100 \mathrm{gm})$. The tannin content was lower in the control sample E (Table 4). Tannin in the leaf samples A, B, C, and D was $0.51,0.58,0.65$, and $0.91 \mathrm{mg} / 100 \mathrm{gm}$ respectively. In food legumes, tannin that occurs naturally reacts with complexes of tanninprotein that form with protein which result to inactivation of some enzymes and protein insolubility as reported by Reddy N.R. et al (1985).

\subsubsection{Estimation of Total Phenol}

The total phenol content in the leaf samples was higher in the control E $(0.35 \mathrm{mg} / 100 \mathrm{gm})$ and it was lower in the leaf sample $D$ (Table 2). The total phenol content in the leaf samples $A, B, C$, and $D$ were $0.26,0.19,0.13$, and 0.09 mg/100gm respectively. In a study conducted by Emurotu and Marvelous Olubunmi (2019), the bean plant grown in crude oil contaminated soil only alkaloid was present while the rest of phytochemicals were absent. Total phenol and flavonoid contents showed a decline of $57.6 \%$ and $41.3 \%$ respectively in the Amaranthuscruentus samples exposed to PAH pollution (Tandey R et al., 2020).

\subsubsection{Estimation of Phytic Acid}

The phytic acid concentration was highest in the control sample $\mathrm{E}$ (Table 2). The phytic acid concentration in the leaf samples $A, B, C$, and $D$ are $1.05,0.87,0.73$ and $0.63 \mathrm{mg} / 100 \mathrm{gm}$ respectively. Phytic acid concentration represents $50-85 \%$ of total phosphorous in plants (Reddy et al., 1985).

Table 2

Phytochemical Screening of Amaranthushybridus

\begin{tabular}{|lllllll|}
\hline $\begin{array}{l}\text { Leaf Samples/ } \\
\text { Phytochemicals }\end{array}$ & $\begin{array}{l}\text { Alkaloid } \\
\text { (mg/100gm) }\end{array}$ & $\begin{array}{l}\text { Flavonoid } \\
(\mathbf{m g} / 100 \mathrm{gm})\end{array}$ & $\begin{array}{l}\text { Saponin } \\
\text { (mg/100gm) }\end{array}$ & $\begin{array}{l}\text { Tannin } \\
(\mathbf{m g} / 100 \mathrm{gm})\end{array}$ & $\begin{array}{l}\text { Total Phenol } \\
\text { (mg/100gm) }\end{array}$ & $\begin{array}{l}\text { Phytic acid } \\
\text { (mg/100gm) }\end{array}$ \\
\hline A (50 mL) & 2.45 & 0.71 & 1.21 & 0.51 & 0.26 & 1.05 \\
\hline B (100mL) & 2.18 & 0.66 & 1.03 & 0.58 & 0.19 & 0.87 \\
\hline C (200mL) & 1.83 & 0.62 & 0.87 & 0.65 & 0.13 & 0.73 \\
\hline D (300mL) & 0.98 & 0.58 & 0.73 & 0.91 & 0.09 & 0.63 \\
\hline E (control) & 3.54 & 0.82 & 1.68 & 0.49 & 0.35 & 1.32 \\
\hline
\end{tabular}

\section{Summary And Conclusion}


Oil pollution is a serious threat to the environment and the ecosystems. It can pollute neighbouring soil, surfaces and ground water; it may damage ecosystems and negatively affect the health of plants, animals and human beings.

Spent engine oil affects the biological, physical, chemical and microbiological components of the soil and hence, it is affecting the growth, development, productivity and yield of plants.

Spent engine oil pollution changes the $\mathrm{pH}$ of the soil and thereby affects the physical, chemical and biological properties of the soil. Pore spaces in the soil might be clogged which could reduce soil aeration and water infiltration. It increases the bulk density subsequently affecting plant growth, length of the shoot, number of leaves, etc. Here, a preliminary study was done on the effects of spent engine oil at different treatment concentrations on soil characteristics and some selected phytochemicals of Amaranthushybridus. Spent engine oil had a prominent negative impact on the soil characteristics, plant growth and the phytochemical content of Amaranthushybridus. This study revealed that as the treatment concentration increased, the soil characteristics are severely affected by spent engine oil pollution and it progressively reduced the fertility of the soil.

The most critical soil parameters like $\mathrm{pH}$, organic carbon, bulk density, particle density, etc were got increased and electrical conductivity, nitrogen, phosphorus, potassium, water holding capacity, and porosity were decreased as the concentration of spent engine oil in the soil increased. The phytochemicals found in the leaf samples such as alkaloids, flavonoids, saponin, total phenol phytic acid, etc are reduced and the tannin is increased in the treatment concentrations. The present study reveals the effects of spent engine oil soil characteristics and selected phytochemicals in Amaranthushybridus. Amaranthushybridus that survived in contaminated soils became stunted. The discharge of spent engine oil in land should be prohibited because of its adverse effect on growth and development of plants. Consequently, the need to encourage the protection of farmlands and surroundings against the disposal of the oil cannot be overemphasized. Additionally, it increased the accumulation of harmful substances in plants which in turn, seriously impact the economy and human health. However, the intensity of the impact depends on the type of derivative found in the petroleum- derived products. Bioremediation supported by the utilization of microorganisms is an advantageous solution that helps in improving the growth of plants, also helps to reducing the harmful effects of petroleum-derived products.

Nevertheless, to assess the full picture of the effects of spent engine oil, we recommend extending the scope of this study to soil microbiota in relation to changes observed in soil properties. Also, the extent of the current study can be widened via performing a detailed investigation the entire nutritional and anti-nutritional profiling and also the physiological measurement by analyzing antioxidants.

\section{Declarations}

Ethics approval and consent to participate- Not applicable

Consent for publication- Not applicable

Availability of data and materials- Not applicable

Competing interests- Not applicable

Funding- Not applicable

Authors' contributions- A S performed the review, data collection, a part of analysis and writing of the manuscript; $V$ has contributed interpretation including the editing of manuscript and also the corresponding author; S R performed phytochemical analysis. 
Acknowledgements- The authors would like to thank Department of Environmental Sciences, All Saints College, TVPM for the completion of the work. Library support from the college is also acknowledged.

Authors' information (optional)-

1. Arathy Arunan Swapna, Dept of Environmental Sciences, All Saints' College, Thiruvananthapuram, Kerala

2. Rajani Vijayammal, Assistant Professor, Dept of Environmental Sciences, All Saints' College, Thiruvananthapuram, Kerala

3. Dhanya Surendran Radha, Assistant Professor, Dept of Botany, KSMDB College, Sasthamcotta, Kollam, Kerala.

\section{References}

1. Adam G, Duncan H (2003) The effect of diesel fuel on common vetch (Vicia sativa L.) plants. Environ Geochem Health 25:123-130

2. Adenipekun CO, Kassin AO (2006) Effect of Spent Oil on the Growth

3. Parameters and Moisture Content of Celosia argentea.Environment International. 239: 241-245

4. Agbogidi OM, Enujeke EC (2012) Effects of spent motor oil on soil physico-chemical properties and growth of Arachis hypogea L. Global journal of Bio-science Biotechnology 1(1):7-74

5. Bray RH, Kurtz LT (1945) Determination of total organic and available forms of phosphorus in soils. Soil Science 59:225-229

6. Bremner JM (1965) In: Black C A (ed). Methods in soil analysis, Part 2. Chemical and Microbiological Properties. American Society of Agronomy Inc. Madison, Winsonsin. 1149-1179

7. Camire AL, Clydesdale F (2006) Analysis of phytic acid in foods by HPLC. Journal of Food Science 47:575-578

8. Chun OK, Kim DO, Lee CY (2003) Superoxide radical scavenging activity of the major polyphenols in fresh plums. Journal of Agriculture Food Chemistry 51:8067-8072

9. Ekundayo JA, Aisueni N, Benka-Coker MO (1989) The Effects of drilling fluids in some waste and burrow pits in western operational areas of Shell Petroleum Development Company of Nigeria Limited on the Soil and Water quality of the areas. Environmental Consultancy Service Group. Consultancy Services Unit. University of Benin, Nigeria

10. Emurotu MO (2019) Consequences of crude oil on some indigenous microorganisms and edible plants in Kogi State University demonstration farm, Anyigba, Nigeria. International Research journal of Environmental Science $8(1): 16-22$

11. Ewetola E, Abosede (2013) Effect of Crude Oil Pollution on some Soil Physical Properties. IOSR Journal of Agriculture Veterinary Science (IOSR-JAVS) 6(3):14-17

12. Ghosh AB, Bajaj JC, FinanulHasan D Singh (1983) Soil and water testing methods. Laboratory Manual. 21-22

13. JoyammaVarkey SS, Nair (2019) Phytochemical, Physico Chemical and Elemental Analysis of Leaves and Stem of Pothosscandens Linn. International Journal of Pharmacognosy Phytochemical Research 11(2):37-43

14. Kayode J, Olowoyo O, Oyedeji A (2009) The effects of used engine oil pollution on the growth and early seedling performance of Vignauniguiculata and Zea mays. Research Journal of Soil Biology 1:15-19

15. Kucharski J, Jastrzębska E (2005) Effect of heating oil on the count of microorganisms and physicochemical properties of soil. Polish Journal of Environmental Studies 14:189-198

16. Makkar HP, Siddhuraju P, Becker K(2007) Methods in molecular biology: plant secondary metabolites, Totowa: Human Press. 93-100

Page 9/11 
17. Nwite JN, Alu MO (2015) Effect of different levels of spent engine oil on soil properties, grain yield of maize and its heavy metal uptake in Abakaliki, Southeastern Nigeria. Journal of Soil Science Environmental Management 6(4):92-99

18. Odjegba VJ, Atebe JO (2007) The effect of used engine oil on carbohydrate, mineral content and nitrate reductase activity of leafy vegetable (AmaranthushybridusL.). Journal of Applied Science Environmental Management 11(2):191-196

19. Odjegba VJ, Sadiq AO (2002) Effects of spent engine oil on the growth parameters, chlorophyll and protein levels of Amaranthushybridus L. Environmentalist 22:23-28 0

20. Ogboghodo A, Iruaga EK, Osemwota IO, Chokor JU (2004) An assessment of the effects of crude oil pollution on soil properties, germination and growth and maize (Zea mays) Using two crude types- Forcados Light and Escravos Light. Environmental Monitoring Assessment 96:142-152

21. Okonokhua BO, Ikhajiagbe B, Anoliefo GO, Emede TO (2007) The effects of spent engine oil on soil properties and growth of maize (Zea mays L.). Journal of Applied Science Environmental Management 11:147-152 0

22. Olayinka B. U., Arinde O. O (2012) Effects of Spent Engine Oil on Germination and Seedling Growth of Groundnut (Arachishypogaea L.). Insight Ethnopharmacology. 2: 5-9.

23. Blessing O-O, Chukwuemaka MB, Alozie (2019) Germination, Phytochemical Composition and Oxidation Products of AbelmoscheusEsculentus (Okra) Plant Cultivated on Spent Engine Oil Polluted Soil. 3: 1-10

24. Otobong B, Iren., Victoria F, Ediene (2017) Effect of Spent Engine Oil Discharge on Soil Properties in Selected Automobile Workshop in Calabar, Cross River State, Nigeria. International Journal of Innovative Science Engineering Technology 4(2):391-401

25. Oyem I Lawrence (2013) Effects of Crude Oil Spillage on Soil Physico-Chemical Properties in Ugborodo Community. International Journal of Modern Engineering Research (IJMER) 3(6):3336-3342

26. Rasaiah V, Voroney RP, Groeneveit PH, kachanoski RG (1990) Modification of soil water retention and hydraulic conductively in oily waste. Soil Technology 3:367-375

27. Reddy NR, Pierson MD, Sathe SK, Salunkhe DK (1985) Dry bean tannins: a review of nutritional implications. Journal of American Oil Chemists' Society 62(3):541-549

28. Sawarkar SD (2012) Determination of Soil pH and Electrical Conductivity. CAFT on Advances in Agrotechnologies for improving soil, plants and Atmosphere System. 11-31

29. Selvakumar S, Vimalanban S, Balakrishnan G (2019) Quantitative determination of phytochemical constituents from Anisomelesmalabarica. MOJ Bioequivalence Bioavailability 6(1):19-21

30. Tandey R, Chouhan KBS, Sen KK (2020) Physiological and biochemical responses of Amaranthuscruentus to polycyclic aromatic hydrocarbon pollution caused by thermal power units. Environmental Science Pollution Research 27:14790-14806

31. Unegbu FO, Akubugwo El, Iweala EJ, Uhegbu OC (2012) Impact of spent engine oil on soil and the growth of Zea mays $L$ seeds. Scientific Journal of Environmental Science 1(1):1-8

32. Uquetan UI, Osang JE, Egor AO, Alozie EssokaPA (2017) A case study of the effects of oil pollution on soil properties and growth of tree crops in Cross River State, Nigeria. International Research Journal of Pure Applied Physics S. I(2):19-28 5(

33. Viji.,Prasanna P, Rajesh (2012) Assessment of water holding capacity of major soil series of Lalgudi, Trichy, India. Journal of Environmental Research and Development. 7(1A)

34. Wyszkowski M, Wyszkowska (2005) Effect of enzymatic activity of diesel oil contaminated soil on the chemical composition of oat (Avena sativa L.) and maize (Zea mays L). Plant Soil Environment 51:360-367 
35. Zshishen J, Mengcheng T, Jianming W (1999) The determination of flavonoid contents in mulberry and their scavenging effects on superoxide radicals. Food Chem 64:555-559

\section{Figures}

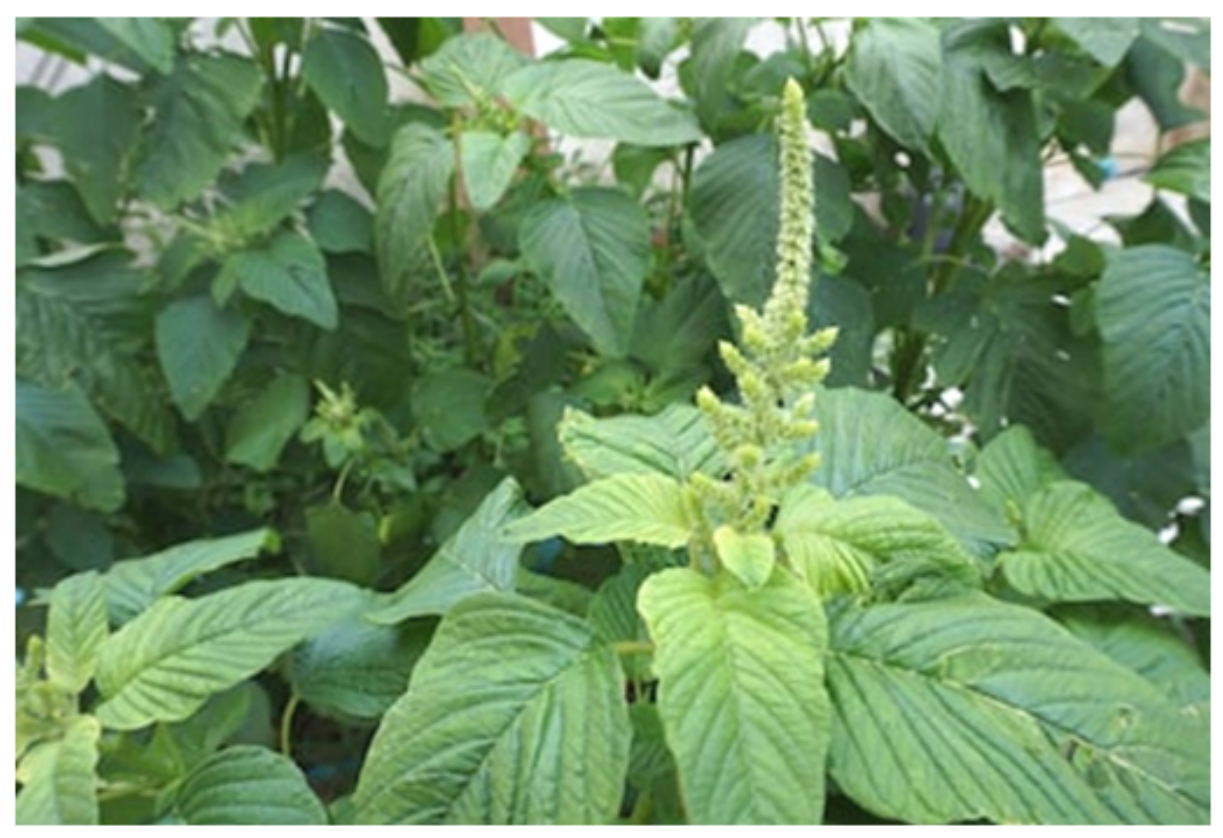

Figure 1

Plate 1: Amaranthushybridus 